\title{
PENCEGAHAN TRANSMISI VIRUS HEPATITIS B PADA MASA PERINATAL
}

\author{
Aditya Bustami* $\diamond$, Anita** \\ *Fakultas Kedokteran Universitas Lampung \\ **Jurusan Keperawatan Poltekkes Kemenkes Tanjungkarang \\ $\checkmark$ Coresponding Outhor: adityabustami@gmail.com
}

\begin{abstract}
Hepatitis adalah peradangan pada sel-sel hati, yang bisa disebabkan oleh infeksi (virus, bakteri, parasit), obatobatan (termasuk obat tradisional), konsumsi alkohol, lemak yang berlebih dan penyakit autoimun . Indonesia merupakan salah satu negara di Asia tenggara yang menduduki salah satu negara dengan endemis hepatitis. Metode dalam penulisan artikel ini adalah studi literatur (literature review). Wanita hamil dengan infeksi virus hepatitis B akut memiliki jalur yang tidak jauh berbeda dengan populasi orang dewasa, tetapi risiko penularan Hepatitis B ke neonatus meningkat pada masa kehamilan, saat infeksi akut terjadi. Infeksi Hepatitis B kronis biasanya dapat meningkat setelah melahirkan. Risiko penularan perinatal tertinggi pada wanita dengan tingkat viraemia tinggi; hal ini menjelaskan kegagalan imunoprofilaksis. Penularan terbesar terjadi kepada bayi yang dilahirkan oleh ibu dengan positif hepatitis B. Penularan terhadap bayi terjadi ketika masih dalam kandungan, saat melahirkan dan setelah persalinan. Pencegahan hepatitis B dapat dilakukan dengan melakukan skrining pada saat pemeriksaan kehamilan pertama. Untuk menurunkan angka transmisi penularan hepatitis B, dianjurkan ibu hamil dengan positif hepatitis B melakukan persalinan dengan metode sectio caesaria elektif.
\end{abstract}

Kata Kunci: Hepatitis, Perinatal

\section{LATAR BELAKANG}

Infodatin (2017) menyatakan hepatitis adalah peradangan hati yang bisa berkembang menjadi fibrosis (jaringan parut), sirosis atau kanker hati. Hepatitis disebabkan oleh berbagai faktor seperti infeksi virus, zat beracun (misalnya alkohol, obat-obatan tertentu), dan penyakit autoimun. Penyebab hepatitis umumnya adalah virus hepatitis B dan C. Infeksi virus hepatitis B terjadi melalui dua cara, yaitu penularan horizontal dan vertical.

Penularan secara vertikal berupa transmisi dari ibu ke janin. Merry (2001), menjelaskan Mother-to-child-transmission (MTCT) terjadi dari seorang ibu hamil yang menderita hepatitis B akut atau pengidap persisten hepatitis B kepada bayi yang dikandungnya atau dilahirkannya. Penularan virus hepaitis B secara vertikal dibagi menjadi penularan in-utero, perinatal dan post natal. Penularan hepatitis B in-utero ini sampai saat ini belum diketahui dengan pasti, mengingat salah satu fungsi plasenta adalah proteksi terhadap bakteri atau virus. Bayi dikatakan mengalami infeksi in-utero jika dalam satu bulan postpartum sudah menunjukkan $\mathrm{HbsAg}$ positif.

Penularan perinatal adalah penularan yang terjadi pada saat persalinan. Sebagian besar ibu dengan HbeAg positif akan menularkan infeksi hepatitis B secara vertikal kepada bayi yang dilahirkannya sedangkan ibu yang anti-Hbe positif tidak akan menularkannya. Penularan post natal terjadi setelah bayi lahir misalnya melalui ASI yang diduga tercemar oleh virus hepatitis B lewat luka kecil dalam mulut bayi.

Kasus persalinan lama cenderung meningkatkan penularan vertikal jika lama persalinan lebih dari 9 jam. Kehamilan tidak akan memperberat penyakit infeksi virus hepatitis ibu, akan tetapi jika terjadi infeksi akut bisa mengakibatkan hepatitis fulminan yang dapat menimbulkan mortalitas tinggi pada ibu dan bayi. Jika penularan virus hepatitis B dapat dicegah berarti mencegah terjadinya kanker hati secara primer. Budihusodo (2008) menyatakan infeksi akut terjadi pada kehamilan trimester ketiga, persalinan lama dan mutasi virus hepatitis.

WHO (2016) menyatakan pada tahun 2015 diperkirakan terdapat 257 juta orang hidup dengan infeksi hepatitis B kronis dan 
mengakibatkan sekitar 887.000 kematian, sebagian besar berlanjut menjadi sirosis dan karsinoma hepatoseluler. Pada 2016, penderita hepatitis B sebanyak 27 juta orang $(10,5 \%$ penderita mengetahui terinfeksi virus hepatitis $\mathrm{B}$, dan 4,5 juta $(16,7 \%)$ sedang dalam pengobatan. Prevalensi hepatitis B tertinggi di Wilayah Pasifik Barat 6,2\% dan Wilayah Afrika 6,1\%, sedangkan wilayah Mediterania Timur 3,3\%, Asia Tenggara 2,0\%, Eropa 1,6 dan di Amerika, 0,7\% dari populasi terinfeksi.

Patton (2014), menyatakan pada daerah endemis transmisi ibu ke bayi mencapai 25 $30 \%$ dengan risiko infeksi mencapai $60 \%$ selama kehidupan. Sekitar 3,9\% ibu hamil merupakan pengidap hepatitis dengan risiko transmisi maternal kurang lebih sebesar $90 \%$ anak yang tertular secara vertikal dari ibu dengan HBsAg (+) selama tahun pertama kehidupan akan berkembang mengalami Hepatitis B kronis $90 \%$ dan akan menjadi carrier.

WHO 2016 menyatakan Anak-anak yang terinfeksi sebelum usia 6 tahun dapat menjadi infeksi kronis sebesar $30-50 \%$. Anak yang terinfeksi tersebut $25 \%$ meninggal karena penyakit hati kronis atau kanker hati. Maka pencegahan penularan secara vertikal merupakan salah satu aspek yang paling penting dalam memutus rantai penularan Hepatitis B (Kemenkes RI, 2015).

Menurut penelitian Ma, Alla, Li, dkk (2014) menyatakan bayi baru lahir memiliki peluang 90\% menderita HBV kronis setelah terinfeksi virus hepatitis B dan pada anakanak yang berusia kurang dari 3 tahun peluangnya mencapai $50 \%$, tetapi pada orang dewasa peluangnya dapat mencapai $5 \%$. Penularan HBV dari ibu ke janin, selama periode kehamilan atau perinatal, merupakan fase paling penting untuk pencegahan infeksi hepatitis B kronis.

Han, Xu, Zhao dan Yang (2012) menyatakan tingkat infeksi hepatitis B pada wanita usia subur sebanyak $7,18 \%$, dan berisiko menjadi infeksi hepatitis $\mathrm{B}$ kronis. Pencegahan dari ibu ke janin menjadi sangat penting pada periode perinatal. Beberapa strategi pencegahan infeksi virus hepatitis B selama periode perinatal dilakukan dengan vaksinasi hepatitis B yang dikombinasikan dengan imunoglobulin hepatitis B (HBIG) dalam waktu 12 jam setelah kelahiran, hal ini menjadi prosedur standar untuk bayi baru lahir dari ibu positif hepatitis B di Cina.

$$
\text { Goyal \& Muray }
$$

menyatakan analog nukleosida / nukleotida telah terbukti bermanfaat dan relatif aman dalam mengurangi kejadian penularan dari ibu ke janin pada wanita hamil dengan viral hepatitis B yang tinggi. Namun belum berhasil sepenuhnya mencegah karena terdapat sekitar $10 \%$ pada kasus infeksi intrauterin mengalami kegagalan imunoprofilaksis.

Ma, Alla, Li, Minbaev dan Shi, (2014) menjelaskan manajemen infeksi HBV pada kehamilan sulit karena beberapa aspek meliputi: (1) kegagalan imunoprofilaksis pasif aktif pada bayi baru lahir, (2) efek injeksi HBIG periodik pada ibu, (3) keamanan profilaksis antivirus dengan nukleosida / analog nukleotida, (4) manfaat cara persalinan yang berbeda, (5) keamanan menyusui.

Indonesia menjadi negara dengan penderita Hepatitis B ketiga terbanyak di dunia setelah China dan India dengan jumlah penderita 13 juta orang, di Jakarta diperkirakan satu dari 20 penduduk menderita penyakit Hepatitis B. Sebagian besar terinfeksi virus Hepatitis B sejak usia kanak-kanak. Prevalensi penyakit hepatitis meningkat dalam kurun waktu 5 tahun yaitu dari tahun 2013-2018 sebesar 0,2\% menjadi 0,4\% (Riskesdas, 2018).

Program nasional dalam pencegahan dan pengendalian virus Hepatitis B saat ini fokus pada pencegahan penularan ibu ke anak (PPIA), karena 95\% penularan Hepatitis $\mathrm{B}$ adalah secara vertikal yaitu dari ibu yang positif Hepatitis B ke bayi yang dilahirkannya. Sejak tahun 2015 telah dilakukan Kegiatan Deteksi Dini Hepatitis B (DDHB) pada ibu hamil di pelayanan kesehatan dasar (Puskesmas) dan jaringannya. Pemeriksaan Hepatitis B pada ibu hamil dilakukan melalui pemeriksaan darah dengan menggunakan tes cepat/Rapid Diagnostic Test (RDT) HBsAg. HBsAg (Hepatitis B Surface Antigen) merupakan antigen permukaan yang ditemukan pada 
virus hepatitis B yang memberikan arti adanya infeksi hepatitis B (Infodatin, 2017).

Sejak tahun 2015, deteksi dini Hepatitis B pada ibu hamil dilakukan di pelayanan kesehatan dasar (Puskesmas) dan jaringannya. Semua wanita hamil harus melakukan uji hepatitis B untuk mencegah infeksi, apabila hasilnya positif maka harus dirujuk ke dokter spesialis untuk evaluasi lebih lanjut. Berdasarkan uraian di atas maka penting dibahas tentang kajian literatur tentang pencegahan penularan infeksi virus hepatitis B dari ibu pada masa perinatal.

\section{METODE}

Studi ini merupakan suatu tinjauan literatur (Literature review) yang membahas tentang penularan virus hepatitis B masa perinatal. Sumber diperoleh dari literatur meliputi sumber buku, jurnal maupun, sumber dari kementerian kesehatan.

\section{PEMBAHASAN}

Penularan Infeksi HBV Kelompok
yang beresiko tinggi tertular HBV
diantaranya: 1) Bayi dari ibu penderita
hepatitis B, 2) bekerja dengan darah dan produk darah (kecelakaan jarum suntik), 3) pengguna jarum suntik tidak steril/bergantian (Penasun), 4) pengguna tato, tindik, pisau cukur, jarum perawatan wajah, menicure/pedicure tidaksteril, 5) pengguna sikat gigi bergantian dengan penderita. 6) pasangan homosex dan 7) sering berganti ganti pasangan. Penularan HBV perinatal menghasilkan frekuensi infeksi kronis yang tinggi, hingga $90 \%$ pada bayi yang lahir dari wanita dengan HBeAg-positif. Telah diterima secara luas bahwa sebagian besar penularan perinatal terjadi pada atau dekat waktu kelahiran, karena vaksinasi neonatal mencegah infeksi bayi baru lahir di sekitar 80-95\% kasus. Risiko untuk penularan HBV terjadi saat melahirkan yaitu paparan sekresi serviks dan darah ibu.

Transmisi virus HBV dapat terjadi dengan 2 cara yaitu penularan horizontal dan vertikal. Penularan horizontal terdiri dari penularan perkutan, melalui selaput lendir dan mukosa. Mother-to-child-transmission
(MTCT) terjadi dari seorang ibu hamil yang menderita hepatitis B akut atau pengidap persisten HBV kepada bayi yang dikandungnya atau dilahirkannya. Mekanisme penularan $\mathrm{HbsAg}$ terbagi menjadi:

1. Intrauterine Transmission (HBV in utero) Transmisi HbsAg melalui intrauterin paling banyak terjadi. Penularan bisa melalui transmisi seluler melalui sel plasenta dan terinfeksi dari transfer darah ibu ke dalam sistem sirkulasi janin. DNA virus hepatitis B tinggi pada ibu dengan positif HbsAg mampu meningkatkan resiko MTCT virus hepatitis $B$ terutama dalam transmisi virus hepatitis B intrauterin melalui kapiler vili. Kehamilan tidak akan memperberat infeksi virus, akan tetapi jika terjadi infeksi akut dapat mengakibatkan hepatitis fulminan . Polimorfisme pada beberapa gen sitokin, mengkode interferon-g dan faktor nekrosis tumor-a, berkorelasi dengan risiko infeksi intra-uterus dengan virus hepatitis B (Han, $\mathrm{Xu}$, Zhao, Yang, 2012).

\section{Intrapartum Transmission}

Selama proses persalinan, bayi baru lahir memiliki akan terpapar cairan tubuh atau darah yang mengandung virus hepatitis B saat melalui jalan jalan lahir, terutama pada kasus persalinan lama lebih dari 9 jam (Merry, 2001).

\section{Puerperal Transmission}

Penularan virus hepatitis B pada masa nifas terjadi akibat kontak dengan ASI ibu, virus masuk melalui luka kecil dalam mulut bayi, cairan tubuh, darah, dan atau yang lainnya. Upaya pencegahan penularan virus hepatitis B masa perinatal sejak tahun 2015 telah dilakukan Kegiatan Deteksi Dini Hepatitis B (DDHB) pada ibu hamil di pelayanan kesehatan dasar (Puskesmas) dan Jaringannya.

Pemeriksaan Hepatitis B pada ibu hamil dilakukan melalui pemeriksaan darah dengan menggunakan tes cepat/Rapid Diagnostic Test (RDT) HBsAg. HBsAg (Hepatitis B Surface Antigen) merupakan antigen permukaan yang ditemukan pada virus hepatitis B yang memberikan arti adanya infeksi hepatitis B (Infodatin, 2017). 
Berdasarkan penelitian, penggunaan lamivudine, tenofovir atau telbivudine setelah kehamilan 28-32 minggu mampu meminimalkan infeksi rahim dan mencegah infeksi hepatitis B pada neonatal. Terapi antivirus dapat digunakan sejak trimester pertama dan kedua kehamilan, namun untuk mencegah MTCT virus hepatitis B harus dimulai pada trimester ketiga (Lu, Chen, Wang, Ji, Yi, 2014).

Skrining Hepatitis B pada Ibu Hamil

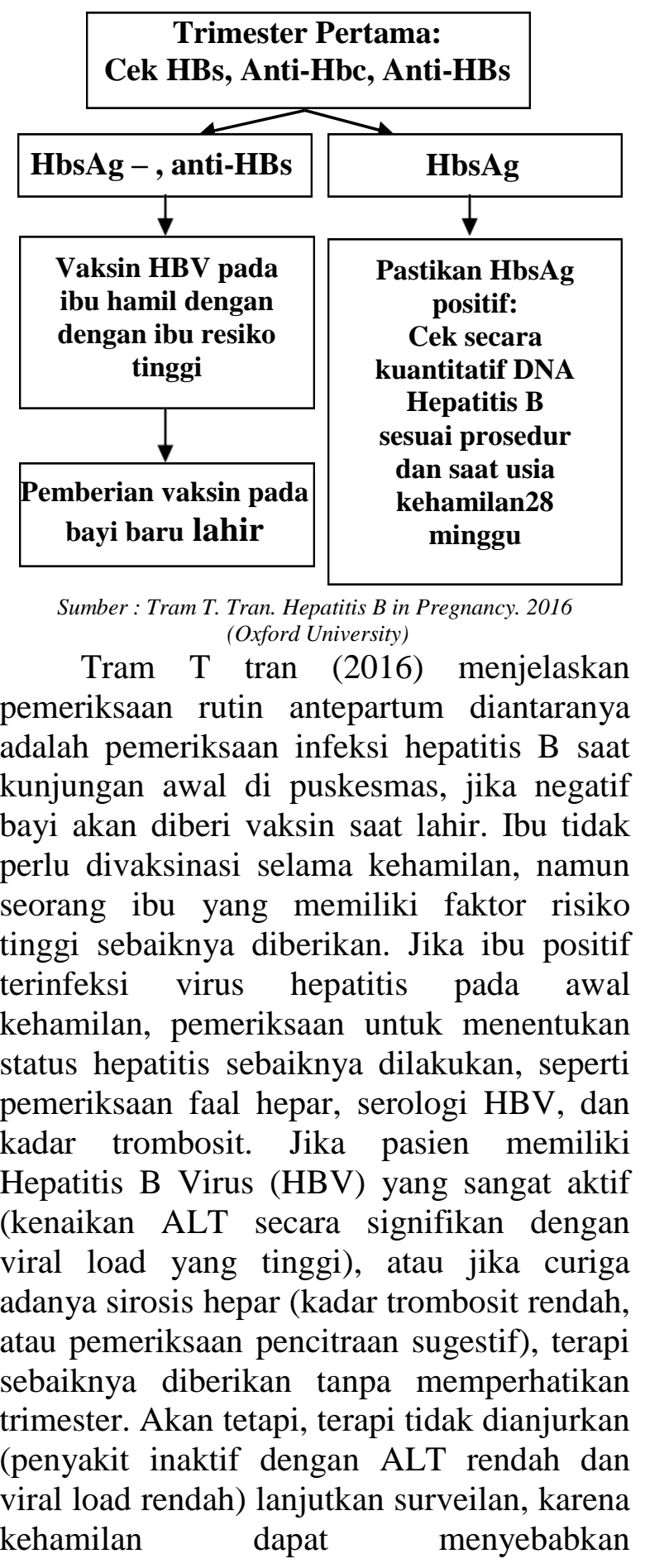

perkembangan hepatitis $\mathrm{B}$, setelah kehamilan maupun beberapa bulan setelah melahirkan.

Ibu yang menderita virus hepatitis B direkomendasikan untuk melakukan pemeriksaan kuantitas viral load HBV DNA saat menjelang akhir trimester kedua (26-28 minggu kehamilan) sehingga keputusan akhir terhadap terapi dapat ditentukan. Pemeriksaan viral load HBV DNA akan memberikan cukup waktu pada trimester ketiga untuk menurunkan viral load secara signifikan setelah terapi diinisiasi, sehingga menurunkan laju transmisi perinatal. Wanita dengan viral load yang tinggi $\left(>10^{7} / \mathrm{ml}\right)$ sebaiknya mempertimbangkan terapi pada awal trimester ketiga (28-30 minggu), setelah mendiskusikan manfaat dan risiko. Terapi dilakukan selama masa kehamilan dan dapat dihentikan setelah melahirkan. Keputusan untuk menghentikan terapi sering dipengaruhi oleh keinginan wanita tersebut untuk kehamilan berikutnya.

Berikut penelitian terkait angka risiko penularan virus hepetitis B dari ibu ke janin. Hasil penelitian Ahmad dan Kusnanto, (2017) menyatakan bahwa penularan infeksi Hepatitis B pada bayi yang dilahirkan dari ibu HBsAg positif yaitu $0 \%$ (0/61). Penularan vertikal dari ibu dengan $\mathrm{HBsAg}$ positif sebesar 20\% (1 dari 5). Dwivedi, Misra SP, Misra V, Pandey, Pant, Singh, Verma (2011) menyatakan $10 \%$ bayi yang lahir dari wanita dengan $\mathrm{HBsAg}$ positif terinfeksi HBV. Ahmad dan Kusnanto, (2017) riwayat pemberian vaksin HBO <12 jam kepada responden dapat mencegah penularan mencapai angka $100 \%$ dan riwayat pemberian HBIg < 12 jam sebesar mencegah tertular sebesar $68.85 \%$ dan tidak diberi HBIg sebesar $31.15 \%$. Tingkat transmisi HBV perinatal adalah $0,0 \%(0 / 132)$ untuk neonatus yang diimunisasi dengan vaksin Hepatitis B saja dan 0,1\% (1/752) untuk pasien dengan vaksin Hepatitis B ditambah HBIg.

Lu, Liang, Wang, dkk (2017). Kemampuan efikasi pemberian vaksin Hepatitis B saja sebesar 75\%, kemampuan efikasi diberi HBIg saja adalah $71 \%$, sedangkan kemampuan efikasi diberi vaksin Hepatitis B dan HBIg adalah 94\%. Kang, Ma, Chen,Yang, dkk (2015) menyatakan di 
beberapa daerah di China vaksinasi universal saja masih merupakan pengobatan yang optimal. Vaksin HB dapat ditoleransi dengan baik dan menimbulkan respons kekebalan yang baik pada bayi. Estimasi efikasi vaksin Hepatitis B yaitu $50-90 \%$.

Program vaksinasi massal berhasil mengurangi tingkat pembawa dan prevalensi HBV. Vaksin saja kemungkinan cukup untuk mencegah penularan HBV pada neonatus HbsAg positif. Lu, Liang, Wang, dkk (2017) menyatakan Riwayat persalinan ibu sebagian besar $(62.30 \%)$ dilakukan secara normal. Bayi yang dilahirkan secara normal dapat terinfeksi HBV sebesar 60\% (15 dari 25 bayi), sedangkan persalinan melalui operasi caesar, tidak ada bukti penularan $0 \%$ (0 dari 4 bayi). Penelitian Dwivedi, Misra SP, dkk (2011) diperoleh tingkat infeksi HBV vertikal yang jauh lebih rendah pada bayi yang dilahirkan secara caesar, dibandingkan dengan kelahiran secara vagina atau normal.

Pilihan caesar untuk ibu $\mathrm{HBeAg}$ positif dengan tingkat awal kelahiran DNA HBV $\geq 1.000 .000$ copies $/ \mathrm{mL}$ bisa mengurangi transmisi vertikal. Hasil penelitian Kim, Hye Jin (2009) menunjukkan bahwa ekstrak curcuma dapat menekan replikasi HBV melalui peningkatan tingkat protein p53 dan ekstrak curcuma dapat digunakan sebagai obat yang aman dan spesifik untuk pasien penyakit hati yang disebabkan oleh infeksi HBV.

Kim, Yoo, Kim, dkk (2009). menjelaskan bahwa replikasi HBV ibu responden terkendali sehingga dimungkinkan daya tular ke bayi menjadi berkurang. Harga HBIg yang relatif mahal $1-5$ juta, menyebabkan sejumlah $47.37 \%$ responden tidak diberi HBIg karena alasan tidak memiliki uang untuk membeli vaksin tersebut. Apalagi bila persalinan sudah dilakukan dengan caesar ditambah harus membeli HBIg maka kemungkinan pasien akan merasa keberatan dalam hal biaya.

\section{Prevalensi Dan Mekanisme Transmisi Vertikal Hepatitis B}

Cheung, Seto \& Wong (2013) membagi mekanisme transmisi vertikal hepatitis B dalam tiga masa kehamilan, yaitu: 1) saat konsepsi yang mana terjadi infeksi germ-line; 2) saat kehamilan melalui kontaminasi darah materna maupun transmisi transplasenta; dan 3) saat kelahiran melalui ruptur membran dan persalinan per vagina.

Lu, Chen, Wang, Ji, Yi (2014) menyatakan tingkat transmisi melalui ketiga mekanisme tersebut berkaitan dengan status HBeAg positif dan kadar Hepatitis B Virus (HBV) DNA yang tinggi. Kejadian transmisi perinatal mencapai $70-90 \%$ pada ibu dengan HBsAg positif dan $\mathrm{HBeAg}$ positif tanpa ibu dengan $\mathrm{HBeAg}$ positif, 25\% pada ibu dengan $\mathrm{HBeAg}$ negatif dan $10-15 \%$ pada ibu dengan $\mathrm{HBeAg}$ negatif/ anti-Hbe positif. Chen, Lin, Hu, dkk (2012) menyatakan Prosentase terinfeksi secara signifikan juga lebih besar pada anak yang lahir dari ibu dengan $\mathrm{HBeAg}$ positif dibandingkan dengan anak dari ibu dengan $\mathrm{HBeAg}$ negatif $(16,76 \%$ vs $1,58 \%, \mathrm{p}=0,0001)$. Anak yang lahir dari ibu dengan $\mathrm{HBeAg}$ positif juga lebih berisiko untuk berkembang menjadi hepatitis kronik dibandingkan dengan anak dari ibu dengan $\mathrm{HBeAg}$ negatif $(\mathrm{OR}=5,46, \mathrm{p}$ $<0,01)$.

Cheung, Seto, Wong (2013) menjelaskan transmisi transplasental (in utero) dapat terjadi pada hanya berkisar 5$15 \%$ dari seluruh kehamilan dengan hepatitis B. Hepatitis $B \quad e$ antigent (HbeAg) merupakan struktur virus hepatitis B satusatunya yang dapat menembus sawar darah plasenta karena memiliki berat molekul yang kecil. Oleh karena terdapat reaksi silang terhadap antigen $\mathrm{e}$ dan antigen $\mathrm{c}$ dalam pengenalan antigen, maka transfer $\mathrm{HBeAg}$ melalui plasenta akan menyebabkan imunotoleransi fetus terhadap Hepatitis $B$ core Antigent $(\mathrm{HbcAg})$. Hal inilah yang dapat menyebabkan infeksi hepatitis B kronik setelah kelahiran.

Huang JM, Huang TH, dkk (2002) Infeksi germ-line terjadi pada oosit atau spermatozoa yang terinfeksi dengan hepatitis B. Virus hepatitis B dapat menembus sawar darah testis dan menyebabkan mutagenesis dari sperma, namun tidak terjadi pada seluruh sperma. 
Sperma mutagenik ini ditemukan pada $14,3 \%$ pria yang terinfeksi hepatitis $\mathrm{B}$.

Nie, Jin, Zhang, Xu, Chen, Zhu (2011) Hepatitis B surface Antigent (HbsAg) juga dapat ditemukan pada $21 \%$ oosit dan embrio ibu dengan HBsAg positif. Virus hepatitis B dapat ditemukan pada nukleus dan sitoplasma oosit dan embrio ibu yang terinfeksi, dan akan bereplikasi seiring dengan pertumbuhan embrio. Kedua hal tersebut menunjukkan bahwa salah satu transmisi hepatitis B dapat disebabkan oleh infeksi germ-line. Faktor prediktor infeksi germ-line ini adalah HBeAg positif dan HBV DNA lebih dari $10^{6}$ kopi/mL ( 2 × $\left.10^{5} \mathrm{IU} / \mathrm{mL}\right)$.

Cheung, Seto, Wong (2013) menyatakan transmisi perinatal hepatitis B dapat terjadi pada 70-90\% 3,7\% ibu dengan HBsAg positif dan $9,8 \%$ di antaranya menunjukkan $\mathrm{HBeAg}$ positif. Pada analisis multivariat menunjukkan faktor yang berperan dalam transmisi intrauterin antara lain adalah status $\mathrm{HBeAg}$ positif $(\mathrm{OR}=17,07 ; \mathrm{p}=0,0006)$ dan adanya ancaman persalinan preterm. Ancaman persalinan preterm menyebabkan kebocoran plasenta yang dapat mencampur darah perifer fetus dengan darah ibu, meningkatkan risiko transmisi vertikal. Serum maternal HBV DNA juga menunjukkan korelasi linear terhadap kadar HBV DNA maternal. Rasio transmisi ini mencapai $22,2 \%$ pada ibu dengan serum HBV DNA $>3,0 \times 10^{8}$ $\mathrm{IU} / \mathrm{mL}$. Pada penelitian yang sama, kadar HBV DNA yan tinggi juga berkaitan dengan infeksi transplasenta yang terlihat dengan HBsAg, HBeAg dan HBxAg yang positif pada villous capillary endothelial cells (VCEC).

\section{Upaya Pencegahan Transmisi Vertikal Pre-embryonic \& Assisted Reproductive Therapy}

Practice Committe of American Society (2013) menjelaskan pada pasangan seropositif dan pasangan dengan $\mathrm{HBsAg}$ seronegatif harus diberikan vaksin hepatitis $\mathrm{B}$. Fertilisasi diinisiasi saat titer anti-HBs sudah terdeteksi dalam jumlah yang cukup. Upaya untuk mengurangi kadar HBV DNA dengan mencuci sperma tidak dibutuhkan bila pasangan sudah memiliki antibodi terhadap hepatitis B. Bila wanita dengan HBsAg positif, maka neonatus harus menjalani protokol imunoprofilaksis yang terdiri dari imunoglobulin hepatitis B yang diikuti vaksinasi hepatitis B. Sekuens DNA hepatitis B dapat ditemukan pada sel spermatogoni, spermatosit, spermatid dan sel sertoli. DNA virus juga dapat ditemukan pada cairan ejakulat, baik dalam plasma atau sebagai DNA yang terintegrasi oleh leukosit yang ditemukan dalam ejakulat. Hal ini masih memungkinkan terjadinya transmisi paternofetal hepatitis B walaupun fertilisasi dilakukan dengan assisted procreation.

\section{Tatalaksana Hepatitis B Pada Ibu Hamil}

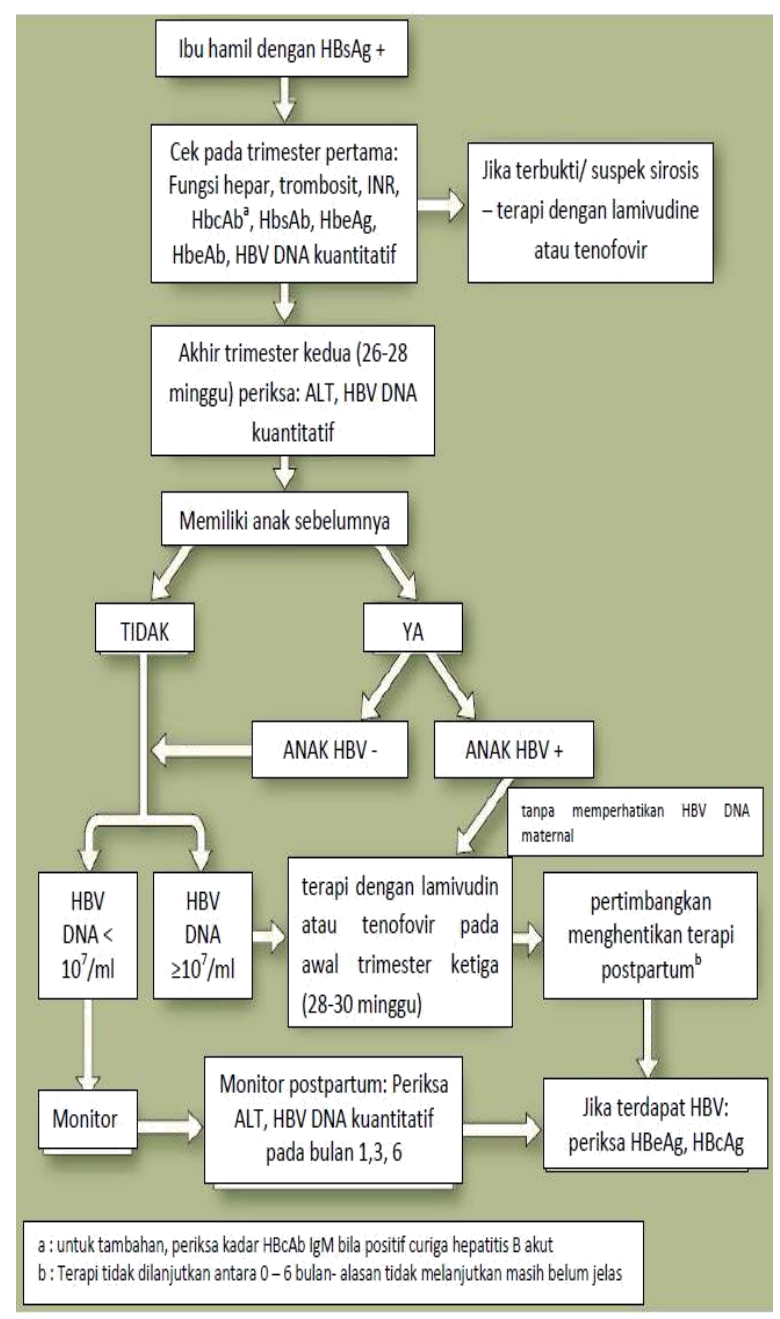

Gambar 2. Algoritma penatalaksanaan hepatitis B pada ibu hamil (Bzowej NH, 2010)

\section{Seksio Sesaria}

Beberapa bukti menunjukkan kesimpulan yang kontradiktif mengenai efektifitas dari seksio sesaria elektif 
sebagai upaya untuk pencegahan transmisi vertikal hepatitis B. Hu, dkk. Honeck, Weigel, Kwon, Alken, Bross (2006) menyebutkan tidak ada perbedaan bermakna antara risiko transmisi hepatitis B dari ibu dengan $\mathrm{HBsAg}$ dan $\mathrm{HBeAg}$ positif yang menjalani seksio sesaria elektif dibandingkan dengan persalinan pervaginam, setelah pemberian imunoprofilaksis $(10,3 \%$ vs $8,7 \% ; \mathrm{p}=0,750)$. Studi ini didukung oleh publikasi lain yang menyebutkan bahwa tidak ada perbedaan bermakna antara seksio cesaria elektif dengan persalinan pervaginam untuk pencegahan perinatal hepatitis $B$. Selain itu studi juga menilai bahwa keputusan untuk melakukan seksio sesaria elektif harus melalui pertimbangan yang matang (Hu, Chen, Wen, dkk, 2013).

Studi retrospektif yang dilakukan oleh Pan, Zou, Chen, dkk (2008) menunjukkan hasil sebaliknya. Studi ini menunjukkan bahwa seksio sesaria elektif berhasil menurunkan transmisi hepatitis B hingga setengah dari transimisi persalinan pervaginam atau seksio sesaria emergensi secara berurutan yaitu $1,4 \%$ vs $3,4 \%$; $\mathrm{p}=$ 0,032 ; atau vs 4,2\%; p <0.020 pada ibu hamil dengan HBV DNA hepatitis $\mathrm{B}(\mathrm{RR}=$ 0,28; IK 95\% 0,20-0,40) dibandingkan plasebo maupun tanpa intervensi.

Nelson, Jamieson, Urphy (2014) menyatakan status $\mathrm{HBeAg}$ ibu dan jumlah serta jadwal pemberian vaksinasi (bulan 1, 2 dan 6 atau 1, 2, 6 dan 12) tidak memberikan perbedaan signifikan terhadap efek protektif hepatitis B. Namun, penambahan hepatitis B imunoglobulin akan menurunkan angka transmisi vertikal yang lebih baik dibandingkan dengan pemberian vaksinasi saja. Kombinasi HBIg dengan vaksinasi menunjukkan penurunan transmisi vertikal hepatitis $B$ bila dibandingkan dengan plasebo atau tanpa intervensi $(\mathrm{RR}=$ 0,50; IK 95\% 0,41-0,60; $\mathrm{p}<0,0001)$ dan bila dibandingkan dengan vaksinasi saja, baik vaksin plasma derived $(\mathrm{RR}=0,49$; $\mathrm{IK}$ $95 \% 0,32-0,74 ; \quad \mathrm{p}=0,0007)$ maupun vaksin rekombinan $\quad(\mathrm{RR}=0.50 ; \quad \mathrm{IK}$ 95\%:0,44 - 0,62; $\mathrm{p}<0,0001)$. Tidak ada perbedaan signifikan antara jumlah suntik imunoglobulin dan status $\mathrm{HBeAg}$ ibu terhadap efek proteksi transmisi vertical.
Walaupun dengan hasil yang sangat baik, namun protokol imunoprofilaksis ini masih menunjukkan kegagalan pada sebagian kecil populasi. Sebanyak 5-10\% bayi yang lahir dari ibu dengan hepatitis $\mathrm{B}$ menunjukkan HBsAg seropositif pada 24 minggu kehidupan (Chen, Lin, $\mathrm{Hu}$, Lee,Lin, Yang et al, 2012 \& Shi, Li, Ma, Yang, 2010). Faktor risiko terjadinya kegagalan imunoprofilaksis antara lain status $\mathrm{HBeAg}$ ibu yang positif dan kadar HBV DNA ibu lebih dari $10^{6} \mathrm{kopi} / \mathrm{mL}$ dengan risiko relatif secara berturut-turut yaitu 31,74 (IK 95\% 3,88-259,38) dan 22,58 (IK 95\% 4,75-107,40) (Lin, Guo, Zhou dkk.,2014).

Pan, Zou, Chen Zhang X, dkk (2013) dalam penelitiannya menstratifikasi rasio kegagalan imunologis pada pasien yang mendapatkan imunoprofilaksis berdasarkan kadar HBV DNA materna prenatal. Stratifikasi diikuti dengan rasio kegagala lebih dari $10^{6}$ IU/mL. Pemilihan metode persalinan pada imunologis adalah sebagai berikut: HBV DNA <6 log 10; 6,6pasien hepatitis $\mathrm{B}$ harus dipertimbangkan dengan baik, mengingat morbiditas ibu dan anak yang terjadi pada seksio sesaria elektif. Hal tersebut telah diantisipasi di Amerika serikat melalui kebijakan yang tidak merekomendasikan seksio sesaria pada pasien hepatitis B dengan tujuan menurunkan transmisi.

\section{Imunoprofilaksis}

Khumaedi, AI, Gani, RA, Hasan, I (2016) menyatakan bahwa pada daerah endemis diantaranya Asia Tenggara, transmisi hepatitis B dari ibu ke bayi mencapai 25-30\% dengan risiko infeksi mencapai $60 \%$ selama kehidupan. Dengan demikian, diperlukan upaya pencegahan transmisi tersebut dengan memperhatikan kemungkinan kegagalan imunoprofilaksis. Imunoprofilaksis dinilai sebagai bagian terpenting dalam pencegahan transmisi vertikal hepatitis $\mathrm{B}$ dan konsekuensinya. Beberapa antivirus yang dapat digunakan dalam upaya pencegahan tersebut diantaraya yatu lamivudin, telbivudin dan tenofovir. 


\section{Peran Antivirus Dalam Pencegahan Transmisi Vertikal}

Sanityoso, Andri (2009) menjelaskan dalam pedoman European Association for the Study of the Liver (EASL) disebutkan bahwa pencegahan transmisi vertikal ditujukan terutama pada ibu hamil dengan $\mathrm{HBeAg}$ atau dengan kadar $\mathrm{HBV}$ DNA sangat tinggi. EASL merekomendasikan penggunaan lamivudin, tenofovir dan telbivudin pada trimester ketiga dan dihentikan pada tiga bulan post partum. Pada konsensus penatalaksanaan hepatitis B yang diterbitkan oleh Perhimpunan Peneliti Hati Indonesia (PPHI) dalam Budihusodo (2008) disebutkan bahwa penggunaan antivirus pada wanita hamil harus mempertimbangkan keuntungan dan kerugian dari terapi tersebut. PPHI merekomendasikan pemberian antivirus pada ibu hamil dengan serum HBV DNA lebih dari $10^{6} \mathrm{IU} / \mathrm{mL}$ pada trimester ketiga untuk mencegah transmisi vertikal atau pada kondisi dekompensasi hati berat. Secara umum, modalitas terapi hepatitis B yang tersedia saat ini adalah interferon dan analog nukleos(t)ida. Interferon itu sendiri merupakan kontraindikasi kehamilan. Lamivudin, adefovir dan entecavir termasuk dalam kategori C bila digunakan selama kehamilan, sedangkan telbivudin dan tenofovir merupakan kategori B.

\section{Lamivudin}

Permenkes no 52 tahun (2017) menjelaskan bahwa pemberian lamivudin minggu 32 kehamilan hingga 4 minggu post partum akan menurunkan serum HBV DNA sebanyak $2 \log _{10}$ sebelum persalinan. Lamivudin juga dapat menurunkan transmisi vertikal hingga $17 \%$ dibandingkan dengan imunoprofilaksis saja $39 \%(\mathrm{p}=0,014)$ yang dilihat dari seropositif $\mathrm{HBeAg}$. Pemberian lamivudin pada trimester ketiga juga akan menurunkan kemungkinan terjadinya infeksi intrauterin bila dibandingkan dengan kelompok imunoprofilaksis saja $(13 \%$ vs $41 \% ; \mathrm{p}=0,0001)$.

Infodatin (2017) menjelaskan tentang studi oleh Yu, dkk. yang menunjukkan efek proteksi lamivudin (pada pemberian trimester kedua dan ketiga kehamilan) yang lebih baik dibandingkan dengan kelompok imunoprofilaksis $\quad(100 \%$ vs $92,31 \%$; $\mathrm{p}<0,05)$. Lamivudin dapat menurunkan HBV DNA materna hingga 4,56 $\log _{10}$ $\left( \pm 1,52 \log _{10}\right)$ dan semakin berkurang 3,57 $\log _{10}\left( \pm 1,59 \log _{10}\right)$. Pada studi tersebut juga menunjukkan keberhasilan lamivudin untuk menginduksi serokonversi HBV DNA sebelum persalinan mencapai $30,85 \%$. Penelitian ini juga dapat menekan rasio transmisi intrauterin hingga 9,57\%. Pemberian lamivudin pada kehamilan juga tidak menimbulkan efek teratogenik atau malformasi genetik, sehingga cukup aman digunakan selama kehamilan.

Salah satu isu yang berkembang dalam penggunaan lamivudin pada pasien dengan hepatitis B adalah resistensi yang timbul setelah pemakaian jangka lama. Karena enzim polimerase hepatitis B virus tidak mempunyai mekanisme proofreading, maka saat replikasi mudah terjadi mutasi. Pemberian lamivudin jangka panjang akan menyebabkan mutasi dengan motif YMDD (tirosin, metionin dan aspartat) pada residu 552 asam amino enzim polimerase yang akan menurunkan efektivitas lamivudin. Namun, mutasi ini jarang terjadi pada pemberian lamivudin dengan durasi kurang dari 36 minggu. Mutasi ini dapat terdeteksi sebanyak 24\% setelah pemakaian selama 52 minggu (Han, Xu, Zhao, Yang, 2012). Hal ini mendasari penggunaan lamivudin dalam trimester ketiga karena dikhawatirkan terjadi mutasi dan resistensi terhadap lamivudin selama kehamilan.

\section{Telbivudin}

Studi prospektif yang dilakukan Goyal, Murray, (2014) pada 450 ibu hamil dengan HBeAg dan HBsAg positif menunjukkan bahwa pemberian telbivudin pada trimester kedua dan ketiga menurunkan angka transmisi vertikal (yang ditandai oleh HBsAg positif setelah 6 bulan post partum) pada grup telbivudin dibandingkan dengan $14,7 \%$ pada grup imunoprofilaksis saja $(0 \%$ vs $14,7 \%$; p <0,0001). Kadar HBV DNA juga tidak terdeteksi pada 
sebagian besar darah tali pusat bayi baru lahir dari ibu yang diobati dengan telbivudin, apabila dibandingkan dengan kelompok imunoprofilaksis saja $(99,1 \%$ vs $61,5 \%$; $\mathrm{p}<0,001)$. Hasil tersebut juga didukung oleh studi yang lain seperti studi yang dilakukan oleh Pan, et al (2013) \& La Ma et all. (2013) yang meneliti pemberian telbivudin pada usia kehamilan 12-30 minggu.

La Ma et al (2013) menyatakan bahwa telbivudin memiliki superioritas dalam menekan rasio transmisi vertikal dibandingkan dengan imunoprofilaksis saja $(1,9 \%$ vs $17 \%$, intention to treat; $\mathrm{p}=$ 0,03). Telbivudin juga efektif dalam menurunkan serum HBV DNA sebanyak lebih dari $4 \log _{10}$ sebelum persalinan. Studi ini menyatakan tidak didapatkan perbedaan yang bermakna secara statistik antara kelompok telbivudin dan imunoprofilaksis pada usia gestasi dan efek samping.

Studi prospektif Han, dkk (2012), juga menunjukkan telbivudin dapat menurunkan risiko transmisi vertikal dibandingkan dengan imunoprofilaksis $(0 \%$ vs $9,3 \%$; $\mathrm{p}<0,0001$ ), baik pada pemberian trimester kedua atau ketiga kehamilan. Pada studi ini juga dikatakan bahwa tidak ada perbedaan antara usia gestasi dan rasio seksio sesaria. Telbivudin dalam penelitian ini tidak menunjukkan efek, baik teratogenik dan mutagenik. Penelitian G. Muray, La Ma dan Han diatas, menjelaskan bahwa subjek penelitian tidak diperbolehkan untuk menyusui anaknya, dikarenakan keamanan telbivudin selama menyusui tidak dapat dinilai.

\section{Tenofovir}

Tenofovir mempunyai potensi eradikasi virus dan barier resistensi yang lebih baik dibandingkan dengan telbivudin dan lamivudin. Namun, studi mengenai penggunaan tenofovir dalam pencegahan transmisi hepatitis B masih terbatas. Penelitian Celen, dkk telah melakukan studi retrospektif mengenai efektivitas tenofovir dalam pencegahan transmisi vertikal hepatitis B pada 52 wanita hamil. Pada penelitian ini, pemberian tenofovir pada minggu ke-18 hingga 27 kehamilan disertai dengan pemberian protokol imunoprofilaksis dapat mencegah transmisi vertikal hepatitis B dengan tingkat keberhasilan $100 \%$ dibandingkan dengan imunoprofilaksis saja sebesar $917 \% \quad(\mathrm{p}=$ 0,022 ). Penelitian ini juga menunjukkan bahwa tenofovir dapat menurunkan kadar HBV DNA ibu hingga kurang dari 50 IU/mL pada minggu ke-28 postpartum dibangdingkan kelompok kontrol (62\% vs $0 \%, \mathrm{p}<0,001)$. Dalam penelitian tersebut juga disebutkan tenofovir cukup aman digunakan selama kehamilan.

Greenup, dkk meneliti efikasi dan keamanan tenofovir dibandingkan dengan lamivudin dan protokol imunoprofilaksis. Antivirus diberikan pada minggu ke-32 kehamilan hingga 12 minggu post partum. Hasil menunjukkan tenofovir dan lamivudin menunjukkan hasil yang memuaskan. Pada 120 ibu hamil, kelompok yang diberikan lamivudin memperlihatkan tidak ada transmisi vertikal yang terjadi, sedangkan dari grup tenofovir hanya ada 1 bayi dengan HbsAg yang menunjukkan hasil positif pada bulan ke sembilan kehidupan. Sementara itu, pada grup imunisasi didapatkan rasio transmisi vertikal terjadi sebanyak $50 \%$. Transmisi vertikal tersebut disebabkan oleh $\mathrm{HBV}$ DNA yang sangat tinggi sebelum kelahiran. Selain itu, pada penelitian tersebut juga tidak menunjukkan perbedaan bermakna antara defek kongenital dan keluaran klinis obstetri pada subjek penelitian.

\section{Masa Laktasi}

Lamivudin dapat melalui sawar darah plasenta dan diekskresikan melalui ASI. Kadar lamivudin saat persalinan mencapai $67 \mathrm{ng} / \mathrm{mL}$ dan konsentrasi ini akan turun pada 6-24 minggu post partum hingga kadar tidak terdeteksi. Kadar lamivudin per hari yang dikonsumsi oleh neonatus melalui ASI hanya mencapai $2 \%$ dari dosis lamivudin pada neonatus untuk HIV. Tenofovir juga dapat melalui sawar darah plasenta, kadarnya dalam ASI sangat sedikit, maksimal hanya 14 $\mathrm{ng} / \mathrm{mL}$ dan jumlah ini sangat sedikit dibandingkan dengan konsentrasinya dalam darah plasenta maupun serum ibu. Dosis harian yang dapat dikonsumsi oleh neonatus 
melalui ASI juga hanya mencapai $3 \%$ dari dosis neonatus tenofovir yang direkomendasikan untuk infeksi HIV (Ehrhardt S, Xie C, Guo N, Nelson K, Thio CL., 2015) Kedua obat ini sudah diterima sebagai pengobatan pencegahan transmisi vertikal HIV dan dinyatakan aman digunakan saat menyusui. Namun, belum ada pernyataan mengenai rekomendasi penggunaan lamivudin dan tenofovir pada masa menyusui pada infeksi hepatitis B.

\section{Post Partum Flare}

Khumaedi, AI, Gani, RA, Hasan, I (2016) menjelaskan ibu hamil mempunyai mekanisme untuk mencegah penolakan sistem imun ibu terhadap bayi. Pada ibu hamil terjadi toleransi sistem imun terhadap antigen paternal berupa supresi terhadap imunitas seluler walaupun dalam waktu yang sama mempunyai imunitas humoral yang meningkat.

Beberapa mekanisme mendasari toleransi imun ini antara lain adalah shifting Th1-Th2 oleh makrofag pada maternal-fetal interface (membran fetus dan plasenta yang terekspos dengan sistem imun materna). Mekanisme shifting ini berperan dalam menekan respons imun seluler terhadap fetus. Imunosupresi yang terjadi ini yang diikuti oleh pemulihan sistem imun post partum diduga mendasari terjadinya post partum flare. Hal ini menyerupai sindroma rekonstitusi imun pada koinfeksi HIV-HBV pada saat awal inisiasi antiretroviral. Teori tersebut mempunyai 2 implikasi, yaitu: 1) terdapat kemungkinan terjadinya reaktivasi sistem imun dan akselerasi dari progresivitas sirosis maupun dekompensasi hati pasca kelahiran; dan 2) fenomena postpartum flare ini dapat dijadikan sebagai peluang untuk meningkatkan efektivitas antivirus atau bahkan mencetuskan serokonversi spontan.

Ibu hamil yang mendapatkan terapi antivirus selama kehamilan mempunyai risiko yang lebih tinggi untuk terjadi post partum flare (62\% vs $36 \%)$ (Ter Borg, 2008). Giles (2012) menjelaskan post partum flare umumnya ringan dan akan terjadi perbaikan secara spontan. Penggunaan antivirus yang diperpanjang hingga 12 minggu postpartum tidak melindungi pasien terhadap kejadian post partum flare, namun fenomena ini lebih banyak terjadi pada penghentian antivirus postpartum kurang dari 4 minggu dibandingkan dengan 12 minggu (50\% vs $40 \%$; $\mathrm{p}<0,01)$. Oleh karena itu, perlu dilakukan follow up secara ketat selama 6 bulan post partum terutama pada pasien dengan $\mathrm{HBeAg}$ positif dan pasien yang sudah secara dini terapi antivirusnya dihentikan. Manajemen flare pada hepatitis $\mathrm{B}$ harus disesuaikan dengan panduan tatalaksana hepatitis B yang ada.

\section{KESIMPULAN}

Risiko penularan Hepatitis B perinatal tertinggi pada wanita dengan tingkat viraemia tinggi, penularan terbesar terjadi kepada bayi yang dilahirkan oleh ibu dengan positif hepatitis B. Beberapa upaya pencegahan transmisi vertikal dari ibu ke bayi antara lain:

1. Masa Pre-embryonic dan Assisted Reproductive Therapy: a) Pasangan seropositif dan HBsAg seronegatif harus diberikan vaksin hepatitis B. Bila wanita dengan HBsAg positif, maka neonatus harus menjalani protokol imunoprofilaksis yang terdiri dari imunoglobulin hepatitis B yang diikuti vaksinasi hepatitis $B, b$ ) Seksio Sesar: beberapa penelitian kontradiktif mengenai efektifitas dari seksio sesaria elektif sebagai upaya untuk pencegahan transmisi vertikal hepatitis B. Hasil penelitian lain menyatakan bahwa seksio sesaria elektif berhasil menurunkan transmisi hepatitis B setengah dari transimisi persalinan pervaginam. c) Imunoprofilaksis: beberapa antivirus yang dapat digunakan untuk pencegahan penularan hepatitis B diantaranya lamivudin, telbivudin dan tenofovir.

2. Masa Laktasi

Lamivudin dan Tenofovir sudah diterima sebagai pengobatan pencegahan transmisi vertikal HIV dan dinyatakan aman digunakan saat menyusui. Namun, belum ada rekomendasi penggunaan lamivudin dan tenofovir pada masa menyusui. 
3. Post Partum Flare: Ibu hamil yang mendapatkan terapi antivirus selama kehamilan berisiko lebih tinggi mengalami post partum flare dan akan terjadi perbaikan spontan, diperlukan Follow up ketat selama 6 bulan. Manajemen flare harus disesuaikan dengan panduan tatalaksana hepatitis B.

\section{DAFTAR PUSTAKA}

Ahmad, N, Kusnanto, H (2017). Prevalensi infeksi virus Hepatitis B pada bayi \& anak yang dilahirkan ibu dengan HBsAg positif. Berita kedokteran Masyarakat. 33(11): 515-520.

American College of Obstetricians and Gynecologists. ACOG Practice Bulletin No. 86: Viral Hepatitis in pregnancy. Obstetrics and gynecology. 110(4): 941.

Laksmi, Purwita W, Mansjoer A, Alwi I, Setiati S, et al. (2008). Penyakitpenyakit pada kehamilan: peran seorang internis. Interna Publishing: Jakarta.

Celen M, Mert D, Ay M, Dal T, Kaya S, Yildirim N, et al. (2013). Efficacy and safety of tenofovir disoproxil fumarate in pregnancy for the prevention of vertical transmission of $\mathrm{HBV}$ infection. World J Gastroenterol. 19(48): 93779382.

Cheung KW, Seto MT \& Wong SF. (2013. Towards complete eradication of hepatitis $B$ infection from perinatal transmission: review of the mechanisms of in utero infection and the use of antiviral treatment during pregnancy. Eur $J$ Obstetr Gynecol Reprod Biol. 169(1):17-23.

Chen HL, Lin LH, Hu FC, Lee JT, Lin WT, Yang YJ, et al. (2012). Effects of maternal screening and universal immunization to prevent mother- toinfant transmission of HBV. Gastroenterology. 142(4):773-781.

Dwivedi M, Misra SP, Misra V, Pandey A, Pant S, Singh R, Verma M. (2011). Seroprevalence of hepatitis B infection during pregnancy and risk of perinatal transmission. Indian Journal of Gastroenterology. 30(2): 66.

Ehrhardt S, Xie C, Guo N, Nelson K, Thio CL. (2015). Breastfeeding while taking lamivudine or tenofovir disoproxil fumarate: a review of the evidence. Clin Infect Dis. 60(2): 275-278.

Giles M, Visvanathan K, Lewin S, Sasadeusz J. (2012). Chronic hepatitis B infection and pregnancy. Obstetr Gynecol. 67(1): $37-44$.

Goyal, A. Murray, J.M. (2014). The impact of vaccination and antiviral therapy on hepatitis B and hepatitis D epidemiology. P LoS One. 9: 110-143.

Greenup AJ, Tan PK, Nguyen V, Glass A, Davison S, Chatterjee U, et al. (2014). Efficacy and safety of tenofovir disoproxil fumarate in pregnancy to prevent perinatal transmission of hepatitis B virus. J Hepatol. 61(3): 502-507.

Han.G.R, Xu.C.L, Zhao.W, Yang.YF, (2012). Management of chronic hepatitis B in pregnancy, World J. Gastroenterol. WJG 18.

Honeck P, Weigel M, Kwon ST, Alken P, Bross S. (2006). Assisted procreation in cases of hepatitis $\mathrm{B}$, hepatitis $\mathrm{C}$ or human immunodeficiency virus infection of the male partner. Hum Reprod. 21(5): 1117-1121

Huang JM, Huang TH, Qiu HY, Fang XW, Zhuang TG, Qiu JW. (2002). Studies on the integration of hepatitis B virus DNA sequence in human sperm chromosomes. Asian J Androl. 4(3): 209-212

Hu Y, Chen J, Wen J, Xu C, Zhang S, Xu B, et al. (2013). Effect of elective cesarean section on the risk of motherto-child transmission of hepatitis B virus. BMC Pregnancy Childbirth. 13: 119.

Infodatin (2017). Situasi Penyakit Hepatitis $B$ di Indonesia tahun 2017, ISSN 24427642

Kang W, Ding Z, Shen L, Zhao Z, Huang G, Zhang J, et al. (2014). Risk factors associated with immunoprophylaxis failure against mother to child 
transmission of hepatitis B virus and hepatitis B vaccination status in Yunnan province, China. Vaccine. 32(27): 3362-2366.

Khumaedi, AI, Gani, RA, Hasan, I (2016) Prevention of Hepatitis B Vertical Transmission: Focus on Antenatal Antiviral Administration. Jurnal Penyakit Dalam. 3(4).

Kim HJ, Yoo HS, Kim JC, Park CS, Choi MS, Kim M, Choi H, Min JS, Kim YS, Yoon SW, Ahn JK. (2009). Antiviral effect of Curcuma longa Linn extract against hepatitis B virus replication. Journal of ethnopharmacology. 124(2): 189-196.

La. Ma, et all. (2013). Towards complete eradication of hepatitis $B$ infection from perinatal transmission: review of the mechanisms of in utero infection and the use of antiviral treatment during pregnancy. J. Obstet. Gynecol. Reprod. Biol. 169:17-23.

Lin X, Guo Y, Zhou A, Zhang Y, Cao J, Yang $M$, et al. (2014). Immunoprophylaxis failure against vertical transmission of hepatitis $B$ virus in the Chinese population: a hospital-based study and a meta-analysis. Ped Infect Dis J. 33(9): 897-903.

Lu LL, Chen BX, Wang J, Wang D, Ji Y, Yi HG, et al. (2014). Maternal transmission risk and antibody levels against hepatitis B virus e antigen in pregnant women. Int J Infect Dis. 28: 41-44.

Lu Y, Liang XF, Wang FZ, Yan L, Li RC, Li YP, Zhu FC, Zhai XJ, Li J, Zhuang $\mathrm{H}$. (2017). Hepatitis B vaccine alone may be enough for preventing hepatitis $\mathrm{B}$ virus transmission in neonates of $\mathrm{HBsAg}(+) / \mathrm{HBeAg}(-) \quad$ mothers. Vaccine. 35(1): 40-45.

Nelson NP, Jamieson DJ, Murphy TV. (2014). Prevention of Perinatal Hepatiti B Virus Transmission. J Ped Infect Dis. 3(Suppl 1):S7.
Nie R, Jin L, Zhang H, Xu B, Chen W, Zhu G. (2011). Presence of hepatitis B virus in oocytes and embryos: a risk of hepatitis B virus transmission during in vitro fertilization. Fertil Steril. 95(5): 1667-1671

Nguyen V, Tan PK, Greenup AJ, Glass A, Davison S, Samarasinghe D, et al. (2014). Anti-viral therapy for prevention of perinatal $\mathrm{HBV}$ transmission: extending therapy beyond birth does not protect against post-partum flare. Aliment Pharmacol Ther. 39(10): 1225-1234.

Ma. L, Alla.N.R, Li. X, Mynbaev.OA, Shi.Z, (2014). Mother-to child transmission of $\mathrm{HBV}$ : review of current clinical management and prevention strategies. Rev. Med.Virol. 24: 396-406.

Merry, V. (2001). Pengelolaan Hepatitis B Dalam Kehamilan Dan Persalinan. [Tesis]. FK Undip Semarang.

Pan CQ, Zou HB, Chen Y, Zhang X, Zhang $\mathrm{H}$, Li J, et al. (2013). Cesarean section reduces perinatal transmission of hepatitis B virus infection from hepatitis B surface antigen-positive women to their infants. Clin Gastroenterol Hepatol. 11(10): 13491355.

Practice Committee of American Society for Reproductive (2013).. Recommendations for reducing the risk of viral transmission during fertility treatment with the use of autologous gametes: a committee opinion. Fertil Steril. 99(2): 340-346.

Sudoyo, Aru W. (2009), Buku Ajar Ilmu Penyakit Dalam Jilid I. Edisi ke-5. Pusat Penerbitan Departemen Ilmu Penyakit Dalam FKUI Jakarta

Ter Borg MJ, Leemans WF, de Man RA, Janssen HL. (2008). Exacerbation of chronic hepatitis B infection after delivery. J Viral Hepatitis. 15(1):3741.

Tran TT. (2016). Hepatitis B in Pregnancy. Clin Infect Dis. 